\title{
Eco-friendly Management of Downy Mildew of Opium Poppy
}

\author{
Ashwani Kumar Patel ${ }^{1 *}$,S. K. Pande ${ }^{2}$, Shivam Singh ${ }^{2}$ and Satyendra Vishwakarma ${ }^{2}$ \\ ${ }^{1}$ Department of Plant Pathology, Acharya Narendra Deva University of Agriculture \& \\ Technology, Kumarganj, India \\ ${ }^{2}$ Acharya Narendra Deva University of Agriculture \& Technology \\ Ayodhya (Faizabad)-224229(U.P), India \\ *Corresponding author
}

\section{A B S T R A C T}

\begin{abstract}
The opium poppy is one of important medicinal plant. Morphine, Codeine and Thebaine alkaloids are the products that are prepared from it. The crop is damaged by a number of fungal diseases, which causes heavy losses. An experiment was designed to evaluate the efficacy of few chemical fungicides and biofungicides, cow urine, buttermilk and botanicals against downy mildew of Opium poppy. Downy mildew (DM) caused by Peronospora arborescens, is a serious disease in Opium poppy (Papaver somniferum L.), which has a world-wide spread. Minimum disease incidence 10.12 per cent was recorded in $\mathrm{T}_{6}$ (Seed treatment and three foliar spray of Ridomyl MZ) followed by 14.21 in $\mathrm{T}_{5}$ (Seed treatment and three foliar spray of Mancozeb @ 0.25 per cent), Maximum reduction (83.82 per cent) in disease intensity was found in $\mathrm{T}_{6}$ followed by $\mathrm{T}_{5}(77.30 \%)$. The untreated plot showed high disease intensity (62.58 per cent) Maximum latex yield (kg/ha) was found in $\mathrm{T}_{6}(40.15 \mathrm{~kg} / \mathrm{ha})$ followed by $\mathrm{T}_{5}(38.33 \mathrm{~kg} / \mathrm{ha}$.) and in control plot it was found minimum, $30.98 \mathrm{~kg} / \mathrm{ha}$, Similar to latex yield the maximum seed yield (13.83 q/ha) was found in $\mathrm{T}_{6}$ followed by $\mathrm{T}_{5}(12.3 \mathrm{q} / \mathrm{ha})$. The minimum seed yield was found in control plot $9.5 \mathrm{q} / \mathrm{ha}$. The use of plant products and 7 days old buttermilk and fresh cow urine were not associated with any health hazards and environmental and soil pollution. These plant product, have not received yet commercial attention, However botanicals and cow urine and buttermilk significantly reduced disease incidence as well as increase the yield.
\end{abstract}

\section{Introduction}

Opium poppy (Papaver somniferum L.) of the family Papaveraceae is a strategic crop for the pharmaceutical industry because it is the only source of morphine, codeine, and thebaine alkaloid drugs. Among the various alkaloids Morphine is a preferred analgesic for cancer patients and codeine is a cough depressant (Kapoor, 1995). Opium poppy is cultivated in different parts of the world such as Tasmania, Afghanistan, Egypt, India and Pakistan for the production of pharmaceutically important alkaloids including morphine, codeine, thebaine and papaverine. These alkaloids are frequently used as an analgesic, anti-tussive and anti-spasmodic in modern medicine. Morphine is given as in form of injection during high pain and Morphine pat is used to cancer patients. Morphine is the major 
alkaloid present in opium ranges from 7-17 per cent mainly used to relieve from almost all type of severe pains. India is among the producing country having area under cultivation in Madhya Pradesh, Rajasthan and Uttar Pradesh. Its cultivation was distributed among the districts of Neemuch Mandsaur and Ratlam in Madhya Pradesh; in Faizabad, Barabanki, Bareilly and Shahjahanpur in Uttar Pradesh, and in Chittoor, Jhalawar, Udaipur and Kota in Rajasthan. In India, it is cultivated on an area of 5328 ha with a production and productivity of 317.86 tones at 70 consistency and $59.65 \mathrm{Kg} / \mathrm{ha}$ and in Rajasthan, it is cultivated on an area of 2503 ha with a production and productivity of 158.4 tones at 70 consistency and 63.28 $\mathrm{Kg} /$ ha during 2013- 14, respectively (Khatik et al., 2016). Downy mildew (DM) of Opium poppy caused by the biotrophic Oomycete Peronospora arborescens (Berk.) (Landa et al.,2007) is one of the most important diseases for this crop worldwide (Yossifovitch, 1929; Khristov, 1943; Kapoor, 1995; Landa et al.,2005). The first symptom appear as small chlorotic leaf lesions, which can evolve to curled and thickened tissues that become deformed and necrotic as the disease develops. The disease caused loss in yield as it reduces the photosynthesis area.

\section{Materials and Methods}

The Experiment was conducted at Horticultural and Medicinal Farm, Acharya N.D. University of Agriculture and Technology, Kumarganj, Ayodhya during 2018-2019 in Randomized Block Design replicated three times consisting 7 treatments with furrow application of Neem cake mixture $100 \mathrm{~g} / \mathrm{m}^{2}$ viz- $\mathrm{T}_{1-}$ Garlic bulb extract @ 10 per cent, $\mathrm{T}_{2}$ - Fresh cow urine @ 10 per cent, $\mathrm{T}_{3}-$ Neem leaf extract @ 10 per cent , T 4 7 days old Buttermilk @ 10 percent, $\mathrm{T}_{5}-$ Seed treatment with $8 \mathrm{~g} / \mathrm{kg}$ seed and foliar spray of Mancozeb @ 0.25 per cent, $\mathrm{T}_{6}-\mathrm{S} . \mathrm{T} 8 \mathrm{~g} / \mathrm{kg}$ seed and foliar spray of Ridomyl MZ @ 0.25 per cent and $\mathrm{T}_{7}$-Control (Untreated). The Opium cultivar NOP-4(Kirtiman) was used in the experiment. Experimental Field was ploughed once with Disc harrow and thrice with cultivar followed by Planking for making a fine tilth. Recommended doses of Nitrogen, phosphorous and Potash were broadcast and mixed thoroughly in soil by light harrowing before sowing .The experimental field having plot size was $3 \times 2$ $\mathrm{m}^{2}$. The Spacing b/w rows was $30 \times 10 \mathrm{~cm}$

\section{Preparation of botanicals}

The leaf extract of Neem and Bulb extracts of Garlic were prepared by cold water extraction method described by Shekwat and Prashad (1971). The samples were washed separately in tap water and finally three changes in distilled water. They were crushed in pestle and mortar by adding distilled water @ 2ml/g fresh weight. The extracts were clarified by passing through two layers of Cheese cloth and finally through Whatmann No. 1 filter paper. The filter extracts were quoted in the study as $100 \%$ extracts.

Preparation of Botanical Pesticides concentration

The appropriate volume of Plant extracts was mixed in sterilized distilled water to make the desired concentration (v/v) for experiments. For Bioassay, double strength concentrations of botanicals were prepared by dissolving 10 $\mathrm{ml}$ of plant extracts in $90 \mathrm{ml}$ of sterilized distilled water, respectively to get the final concentration of 10 per cent.

\section{Observation recorded}

Five plants from each plot were randomly selected and tagged. Observations were recorded on per cent disease control and yield. Yield was recorded after the harvest of the crop. Latex yield was expressed in $\mathrm{kg} / \mathrm{ha}$, and seed yield was recorded in $q / h a$. The 
Disease intensity was calculated by using formulae:

Disease Index- Sum of all individuals rating $\times 100$

No of plant assessed

Max. Disease rating

Percent decrease in disease intensity on the basis of efficacy of different treatment over the control was calculated by following formula,

Percent decrease in Disease intensity $=$

Disease intensity in control - Disease intensity in treatment

Disease intensity in control

Scales used for Downy Mildew given in table 1.

\section{Statistical analysis}

The data, collected for all the characters studied, were subjected to the statistical analysis by adopting 'Analysis of variance' techniques.

\section{Results and Discussion}

The efficacy of chemicals and botanicals biofungicides, Fresh cow Urine and 7 days old buttermilk against Downy mildew disease of Opium Poppy resulted reduction in disease intensity and significantly increases the yield, represented in Table 2. The Minimum disease intensity (10.12 percent ) was recorded in $T_{6}$ (S.T. and three foliar spray of Ridomil MZ) followed by 14.21, 29.06, 30.10, 30.43, 32.43 per cent disease intensity in $\mathrm{T}_{5}$ (S.T. and three foliar spray of Mancozeb @ 0.25 per cent), T1(garlic bulb extract@ 10 per cent), $\mathrm{T}_{3}$ (neem leaf extract @ 10 per cent), $\mathrm{T}_{2}$ (fresh cow urine @ 10 per cent) and $\mathrm{T}_{4}$ (7 days old buttermilk@10 per cent), respectively, on other hand, control (untreated plot) showed high disease intensity (62.58 per cent). Maximum reduction (83.82 per cent) in disease intensity was found in $\mathrm{T}_{6}$ followed by $\mathrm{T}_{5}$ (77.30 per cent), $\mathrm{T}_{1}$ (53.56 per cent), $\mathrm{T}_{3}$ (51.90 per cent), $\mathrm{T}_{2}$ (51.37) and $\mathrm{T}_{4}$ (48.17 per cent). This finding is supported by Sharma et al., (2003) and reported that out of the eight fungicides tested in vitro, Ridomil-MZ proved the most effective with average reduction $(82.41 \%)$ of sporangial formation of Pseudoperonospora cubensis at all the concentrations (500, 700, $1000 \mathrm{ppm})$, while Indofil M-45 was less effective with average reduction of sporangial formation i.e. 69.38 percent at same concentration. Furthermore repeated and continuous use of these Plant Products is not associated with any health hazards and environmental pollution.

Table.1

\begin{tabular}{|c|c|}
\hline Scale & Description of the symptom \\
\hline $\mathbf{0}$ & Leaves free from infection \\
\hline 1 & Small creamy white to light brown spots on leaves covering $<5 \%$ leaf area \\
\hline 2 & $\begin{array}{l}\text { Small creamy white to light brown spots with cottony downy growth covering } 5.1-10 \% \\
\text { leaf area }\end{array}$ \\
\hline 3 & Creamy white to light brown spots with cottony growth covering $10.1-25 \%$ leaf area \\
\hline 4 & Creamy white to light brown spots with cottony growth covering $25.1-50 \%$ leaf area \\
\hline 5 & Creamy white to light brown spots with cottony growth covering $25.1-50 \%$ leaf area \\
\hline
\end{tabular}


Table.2 Effect of seed treatment and foliar spray of fungicides, Plant extracts and biological treatment on intensity of downy mildew of opium poppy under field condition

\begin{tabular}{|l|l|c|c|c|}
\hline S.No & Treatments & Conc \% & $\begin{array}{c}\text { Disease } \\
\text { intensity }\end{array}$ & $\begin{array}{c}\text { Per cent reduction in } \\
\text { disease intensity }\end{array}$ \\
\hline $\mathbf{1}$ & $\mathrm{T}_{1:}$ Garlic Bulb extract @ & $10 \%$ & 29.06 & 53.56 \\
\hline $\mathbf{2}$ & $\mathrm{T}_{2:}$ Fresh cow urine @ & $10 \%$ & 30.43 & 51.37 \\
\hline $\mathbf{3}$ & $\mathrm{T}_{3:}$ Neem leaf extract @ & $10 \%$ & 30.10 & 51.90 \\
\hline $\mathbf{4}$ & $\mathrm{T}_{4:}$ 7 days old Buttermilk & $10 \%$ & 32.43 & 48.17 \\
\hline $\mathbf{5}$ & $\mathrm{T}_{5:}$ S.T*+ Mancozeb MZ & $0.25 \%$ & 14.21 & 77.30 \\
\hline $\mathbf{6}$ & $\mathrm{T}_{6:}$ S.T+ Ridomyl MZ & $0.25 \%$ & 10.12 & 83.82 \\
\hline $\mathbf{7}$ & $\mathrm{T}_{7:}$ Control(Untreated plot) & & 62.58 & 00 \\
\hline & SEm \pm & & $\mathbf{2 . 1 8}$ & \\
\hline & CD @ $\mathbf{5 \%}$ & & $\mathbf{0 . 9 2}$ & \\
\hline & $\mathbf{C V}$ & & $\mathbf{2 . 8 2}$ & \\
\hline
\end{tabular}

Table.3 Effect of seed treatment, foliar spray of plant extracts, fungicides, cow urine, buttermilk and fungicides on latex yield and seed yield

\begin{tabular}{|l|l|c|c|c|}
\hline S.No & Treatments & Conc \% & Latex yield kg/ha & Seed yield q/ha. \\
\hline $\mathbf{1}$ & $\mathrm{T}_{1:}$ Garlic Bulb extract & $10 \%$ & 37.10 & 11.9 \\
\hline $\mathbf{2}$ & $\mathrm{T}_{2:}$ Fresh cow urine & $10 \%$ & 33.21 & 10.2 \\
\hline $\mathbf{3}$ & $\mathrm{T}_{3:}$ Neem leaf extract & $10 \%$ & 36.85 & 11.6 \\
\hline $\mathbf{4}$ & $\mathrm{T}_{4:}$ 7 days old Buttermilk & $10 \%$ & 31.56 & 10.5 \\
\hline $\mathbf{5}$ & $\mathrm{T}_{5:}$ S.T*+Ridomyl MZ & $0.25 \%$ & 38.33 & 12.3 \\
\hline $\mathbf{6}$ & $\mathrm{T}_{6:}$ S.T+ Mancozeb MZ & $0.25 \%$ & 40.15 & 13.83 \\
\hline $\mathbf{7}$ & $\mathrm{T}_{7:}$ Control(Untreated plot) & & 30.98 & 9.5 \\
\hline & SEm & & $\mathbf{1 . 4 4}$ & $\mathbf{0 . 4 7}$ \\
\hline & CD@ $\mathbf{5 \%}$ & & $\mathbf{4 . 4 4}$ & $\mathbf{1 . 4 5}$ \\
\hline & CV \% & & $\mathbf{7 . 0}$ & $\mathbf{7 . 1}$ \\
\hline
\end{tabular}

Graph.1 Effect of disease intensity on Latex yield and reduction due to different treatments

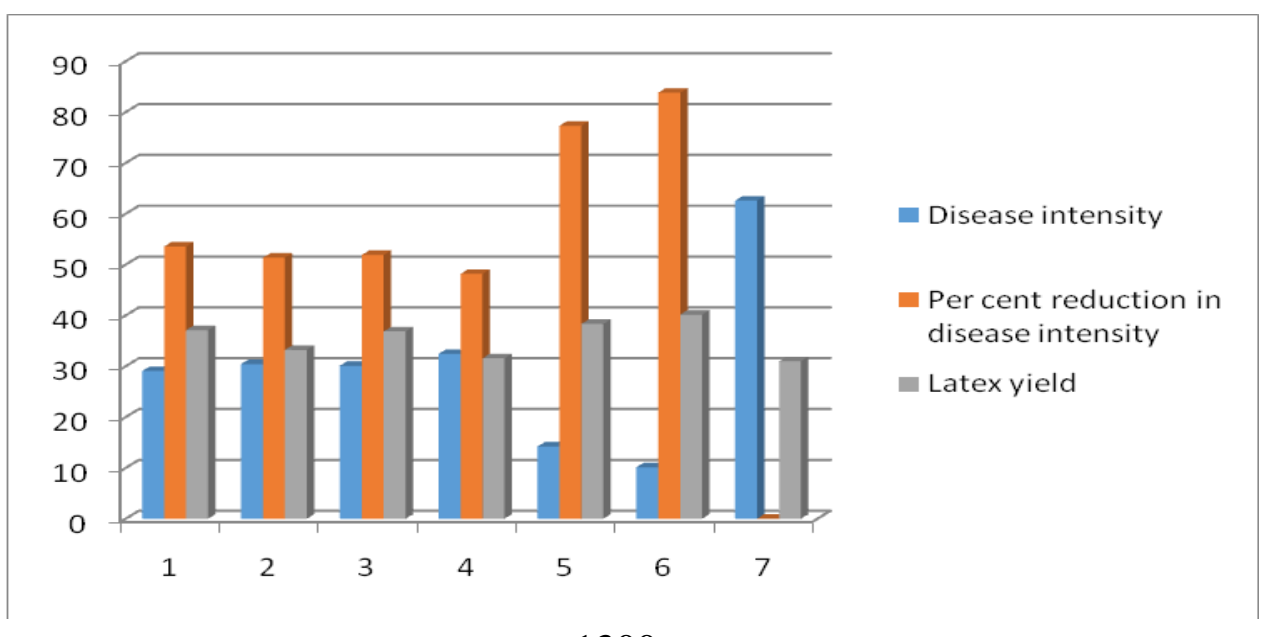


Graph.2 Effect of disease intensity and different treatments on the seed yield

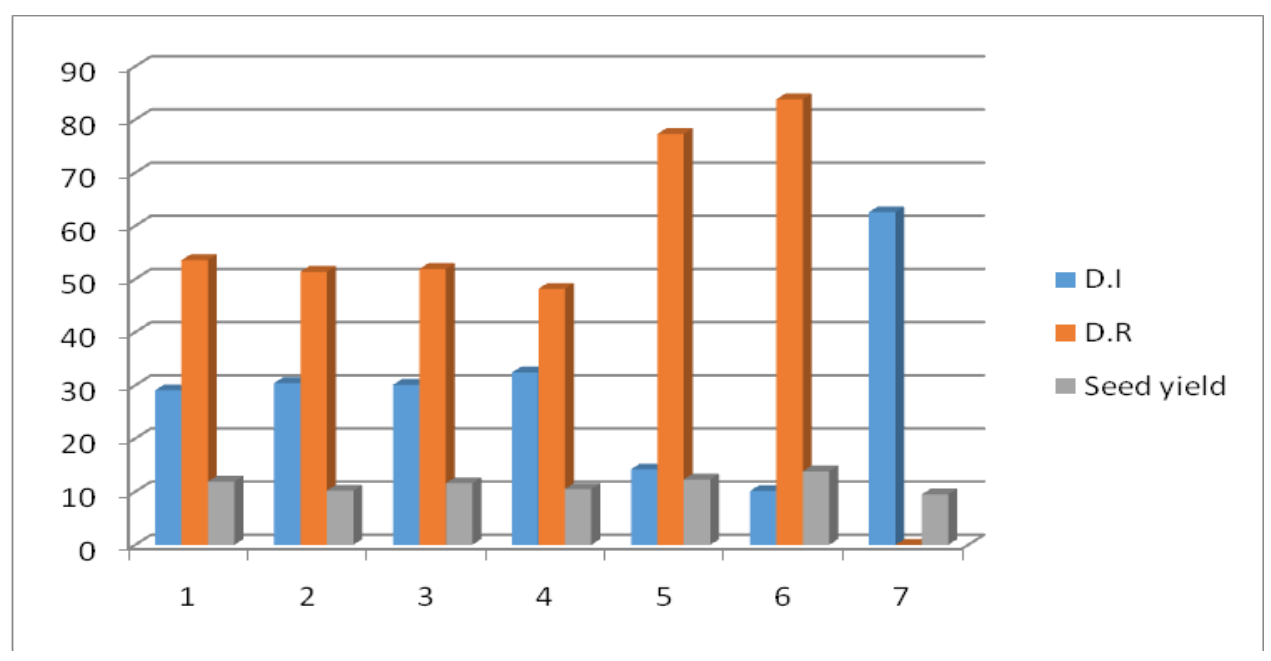

The Graph 1 indicates clearly about the effect of disease intensity on the latex yield and disease reduction due to the different treatment. While in Graph 2 it indicates about the effect of treatments and disease intensity on seed yield.

\section{Acknowledgment}

I want to acknowledge special thanks to Dr. S.K Pande for providing the all the essential thing to carry out my work and I am very thankful to Dr. Sushil sing H.O.D of Acharya Narendra Deva University of Agriculture and Technology for his support and advice. At last I thanks to manager of Farm for his support during my research work which I carried out in the field.

\section{References}

Kapoor, L.D (1995) Opium poppy; Botany, chemistry, and Pharmacology. Binghampton, NY: Haworth Press

Khristov, A. (1943). Fungi causing spot on the balls and moulding the seed of opium poppy. Bulgaria Agricultural Experiment Station Journal, 13, 13-19.

Khatik, C.L., Sharma, S.P., Dodiya, N.S., Maloo, S.R., Joshi, A., Jain, H.K. and
Padiwal, N.K., 2017. Estimate heterosis for latex yield and its related traits in opium poppy (Papaver somniferum L.). Electronic Journal of Plant Breeding, 8(1):288-293.

Landa B. B., Montes-Borrego M, MunozLedesma FJ, Jimenez-Diaz RM. (2007.) Phylogenetic analysis of downy mildew pathogens of opium poppy and PCRbased in planta and seed detection of Peronospora arborescens. Phytopathol 97:1380-90.

Landa, B.B., and Montes,Borrego M, MuñozLedesma F.J., Alcaliber S.A., R. M.Jiménez-Díaz, (2005) First Report of Downy Mildew of Opium Poppy Caused by Peronospora arborescens in Spain. American Phytopathological society $89,(3): 338$

Sharma, D.R.; Gupta, S.K. and Shyam, K.R. (2003). Studies on downy mildew of cucumber caused by Pseudoperonospora cubensis and its management. 33 (2): 246-251.

Shekhawat, P. S. and R. Prasad (1971). Antifungal properties of some plant extract inhibition of spore germination. Indian Phytopath, 24: 800-802.

Yossifovitch, M. 1929. Peronospora arborescens (Berk.) de Bary parasite 
tress important de Papavor Vegetet d. Entomol Agril 16: 235-270. somniferumer Yugoslavia. Rev. Pathol.

\section{How to cite this article:}

Ashwani Kumar Patel, S. K. Pande, Shivam Singh and Satyendra Vishwakarma. 2020. Ecofriendly Management of Downy Mildew of Opium Poppy. Int.J.Curr.Microbiol.App.Sci. 9(08): 1297-1302. doi: https://doi.org/10.20546/ijcmas.2020.908.146 